\title{
AUTONOMOUS NEUTRON FACILITY FOR DETECTING FISSILE NUCLEAR MATERIALS
}

\author{
(D)Eduard L. Kuplennikov*, (D)Mykola I. Ayzatsky, DAlexander N. Vodin, DOlexii S. Deiev, \\ (D) Stanislav N. Olejnik, (DIryna S. Timchenko, DSergii S. Kandybei, Alexander S. Kachan, \\ Larisa P. Korda, Yurii N. Solodovnikov \\ NSC «Kharkov Institute of Physics and Technology», Kharkov, 61108, Akademicheskay 1,Ukraine \\ *Corresponding Author: kupl@kipt.kharkov.ua \\ Received June 20, 2020; revised October 14; accepted October 19, 2020
}

The prospect of creating an autonomous neutron facility for the detection of fissile nuclear materials in samples, including those in
confined volume, is discussed. It is proposed to obtain a reference field of thermal neutrons on the basis of a polyethylene moderator
ball and a portable fast neutrons source, developed at NRC "Accelerator" NSC KIPT based of a continuous electrostatic accelerator
of deuterons. The developed source of thermal neutrons is planned to be used to activate small objects and goods in order to identify
substances prohibited for movement containing to find ${ }^{233} \mathrm{U},{ }^{235} \mathrm{U}$ and ${ }^{239} \mathrm{Pu}$ in their composition. The prompt finding of fissile
elements will indicate about an attempt to transport them illegally. A more thorough inspection can be carried out using special
equipment after the detention of suspicious goods, citizens or vehicles. The possibility of detecting prompt fission neutrons is
considered not only in the traditional way using a polyethylene moderator and proportional ${ }^{3} \mathrm{He}$ detector, but also without application
of any moderator using oxide or semiconductor scintillators. For detection fissile materials the method based on using the high-
energy part of the $\gamma$-spectrum of fission fragments (greater than $4900 \mathrm{keV}$ ), as well, as the approach applied in the passive non-
destructive analysis by the $\gamma$-line with $E_{\gamma}=185.7 \mathrm{keV}$ from ${ }^{235} \mathrm{U}$, are substantiated. It is shown that the proposed facility for the
detection of fissile nuclear materials is able to determine the presence of isotopes ${ }^{233} \mathrm{U},{ }^{235} \mathrm{U}$ and ${ }^{239} \mathrm{Pu}$ in tested objects and goods
with the using non-destructive testing method.

KEY WORDS: fissile nuclear materials, non-destructive analysis, neutron source, moderator, thermal neutrons, fission fragments, prompt neutrons

Виявлення ядерних матеріалів, що діляться, у виробах і вантажах $є$ найважливішим, фактором системи обліку і контролю ядерних матеріалів, безпеки ядерно-енергетичних установок, нерозповсюдження ядерних технологій, припинення обороту елементів поділу у випадку їх несанкціонованого транспортування i т. д. В якості заборонених до перетину кордонів матеріалів слід виділити два основних види: вибухові речовини $і$ елементи поділу. У зв'язку з цим, світовою спільнотою на міжнародному та регіональному рівнях прийнято низку правових актів і одним з них є, зокрема, «конвенція про захист ядерних матеріалів» (1980 рік). Найбільш привабливим 3 точки зору терористів $e^{239} \mathrm{Pu}$, оскільки мінімальна маса кулі з «чистого» металу, що забезпечує протікання самопідтримуваної ланцюгової реакції поділу з ${ }^{9} \mathrm{Be}$ відбивачем товщиною 32 см, усього 2,47 кг [1]. «Чистий» означає $(90-95) \%{ }^{239} \mathrm{Pu},(1-7) \%{ }^{240} \mathrm{Pu}$, вміст інших елементів не перевищує десятих часток відсотка. Для порівняння аналогічна величина для ${ }^{235} \mathrm{U}$ з 93,5\% збагаченням і з ВеО відбивачем 8,9 кг [2].

Існуючі ядерно-фізичні методи неруйнівного контролю, що спрямовані на виявлення та визначення кількості ядер поділу у зразках, включаючи вироби зі складним гетерогенним складом, наприклад, ТВС, їх збагачення і т.д., досить різноманітні. Знайдено цілий ряд рішень цієї задачі і одним з них є активація вантажу тепловими нейтронами (ТН), з подальшою реєстрацією та аналізом продуктів реакції. При взаємодії з ТН стратегічно важливі ядра ${ }^{233,235} \mathrm{U},{ }^{239} \mathrm{Pu}$ діляться, випромінюючи уламки поділу, миттєві нейтрони і $\gamma$-кванти (за час $\sim 10^{-14} \mathrm{i} \sim 10^{-9} \mathrm{c}$, відповідно), запізнілі нейтрони, $\beta$-частинки, антинейтрино. Число запізнілих нейтронів, як правило, становить $\sim 1 \%$ від числа миттєвих. Вони випромінюються зупиненими продуктами поділу після попереднього $\beta$-розпаду за час від сотень мілісекунд до 60 с і енергією $(0,25-0,62)$ МеВ. Що стосується $\gamma$ квантів, то в середньому на однин акт поділу утворюються від 7 до 10 фотонів, а їх енергія близька 1 МеВ. Середня кількість нейтронів, що утворюються в одному акті вимушеного поділу (v) при енергії взаємодіючих частинок 0,025 еВ дорівнює для ${ }^{233} \mathrm{U}-2,48,{ }^{235} \mathrm{U}-2,42 \mathrm{i}{ }^{239} \mathrm{Pu}-2,86$. При енергії вище 0,025 еВ величина $v$ зростає. Енергетичні спектри розглянутих ядер близькі один до одного $[3,4]$, є суцільними, і добре описуються виразом $N(T)=(\varepsilon)^{1 / 2} \times \exp (-E / T)$, де $E$ - кінетична енергія нейтронів, $T=1,31,1,29,1,33$ МеВ, відповідно. Спектри простягаються від 0,01 до $10 \mathrm{MeB}$. Зустрічаються енергії до $18 \mathrm{MeB}$, але їх дуже мало. Максимум енергетичного розподілу знаходиться при енергії 0,7 МеВ. Середня енергія нейтронів поділу близько 2 МеВ. Миттєві нейтрони випромінюються уламками поділу рівноімовірно в усіх напрямках.

Утворені в результаті реакції вторинні частинки, реєструються відповідними детекторами, аналізуються, даючи відповідь, наявні чи відсутні в досліджуваному зразку заборонені ізотопи, їх маса, збагачення і т. д. Очевидно, що метод вимушеного поділу вимагає наявності досить потужного потоку ТН. Таке джерело на базі поліетиленової кулі-сповільнювача і медичного генератора швидких нейтронів був нами запропонований в роботі [5].

(C) E.L. Kuplennikov, M.I. Ayzatsky, A.N. Vodin, O.S. Deiev, S.N. Olejnik, I.S. Timchenko, S.S. Kandybei, A.S. Kachan,

L.P. Korda, Y.N. Solodovnikov, 2020 
Метою цієї роботи $є$ обговорення можливості створення автономної установки для знаходження ядерних елементів поділу у зразках, в тому числі і таких, що знаходяться в замкнутих об'ємах. Створення такого пристрою вимагає ретельного попереднього розгляду, відповідних аналітичних розрахунків, економічного обгрунтування і т. д. Тому основні зусилля першого етапу роботи планується направити на:

1. обгрунтування за допомогою сучасного програмного забезпечення застосування тих чи інших конструктивних елементів, їх розмірів, розташування в просторі та ін.;

2. визначення переліку необхідних приладів і обладнання;

3. розробку і створення опорного нейтронного поля;

4. проведення технічних і організаційних заходів, спрямованих на безпеку обслуговуючого персоналу під час роботи з нейтронним джерелом і матеріалами, що діляться;

5. монтаж стенду для наладки, тестування і підготовки конструкції для введення в експлуатацію.

Відразу ж відзначимо, що в роботі не розглядається можливість знаходження кількості матеріалів, що діляться, визначення ізотопного складу, збагачення і т. д. У принципі, це подальша перспектива другого етапу досліджень.

\section{ДЖЕРЕЛО ОПОРНОГО ПОЛЯ ТЕПЛОВИХ НЕЙТРОНІВ}

При розробці детекторів нейтронного потоку однією з основних проблем $є$ тестування і калібрування приладів, що використовуються. У лабораторній практиці найбільш доступними і широко використовуваними пристроями для градуювання і вивчення характеристик детекторів є конструкції на базі опорних полів радіонуклідних джерел. Це пов'язано з тим, що при розміщенні випромінювачів у різних уповільнюючих середовищах, можна сформувати опорні поля випромінювання 3 різними характеристиками. В якості сповільнювача використовують водневомісне середовище, як правило, поліетилен (ПЕ) через відповідні механічні, хімічні та інші властивості, а також зручності при експлуатації. Номенклатура таких джерел широка. Ïх параметри залежать від виду використаного радіоізотопу, розміру активної зони, конструкції, використаних матеріалів і т.д. Найчастіше перевага віддається двом типам опорних полів, які створюються на базі атестованих випромінювачів ${ }^{252} \mathrm{Cf}[6]$ або ${ }^{239} \mathrm{Pu}-\mathrm{Be}$ [7]. Обидва джерела мають суцільний спектр і високий рівень $\gamma$-фону.

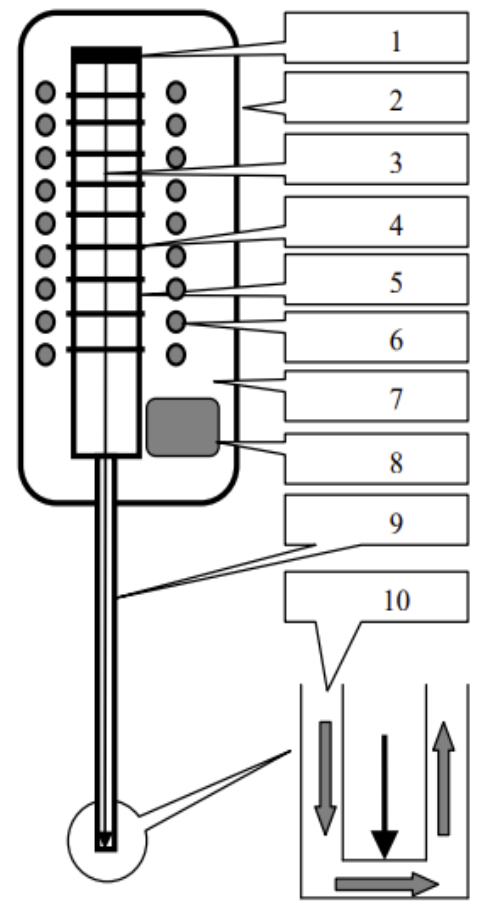

Рис. 1. Блок-схема ПВН. 1 - джерело дейтронів; 2 - кожух; 3 - дейтрони; 4 - прискорювальні електроди;

5 - вакуумная трубка; 6 - градиєнтні кільця;

7 - елегаз; 8 - вакуумний насос;

9 - іонопровід; 10 - вода використовувалися в ННЦ ХФТІ, починаючи 3 2000-х (див., зокрема, роботу [11]). 3 цією метою застосовувався лінійний прискорювач електронів ЛПЕ-300. Енергія

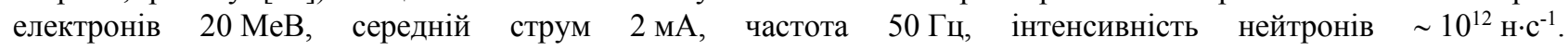

У даній роботі пропонується, з використанням досвіду [6-7], створити опорне поле ТН на основі ПЕ кулі-сповільнювача i портативного випромінювача нейтронів (ПВН) НДК «Прискорювач» ННЦ ХФТІ, розробленого на основі електростатичного прискорювача дейтронів [8-9]. На рис. 1 показана блок-схема ПВН.

Принцип роботи установки наступний. Прискорені дейтрони електростатичного прискорювача направляються у вузький іонопровід, пройшовши який, частинки фокусуються на ${ }^{9} \mathrm{Be}$ мішені розміром $10 \times 10$ мм. Довжина трубки для прискорення $\leq 0,6$ м. Нейтрони генеруються в результаті реакції ${ }^{2} \mathrm{H}+{ }^{9} \mathrm{Be} \rightarrow{ }^{10} \mathrm{~B}+\mathrm{n}$. Очікуваний потік нейтронів $\sim 10^{9} \mathrm{H} \cdot \mathrm{c}^{-1}$ у кут $4 \pi 3$ середньою енергією $\sim 2,5$ МеВ. Перевагою даної конструкції (у порівнянні $3[6,7]$ i подібними аналогами) $€$ відсутність потужного, стаціонарного джерела випромінювання. Нейтрони генеруються тільки під час санкціонованого включення ПВН. Крім того, використання ${ }^{252} \mathrm{Cf}$ i ${ }^{239} \mathrm{Pu}-\mathrm{Be}$ випромінювачів коштує значно дорожче, ніж робота запропонованого приладу. Додаткова зручність полягає в тому, що опромінення доброякісних i злоякісних новоутворень (як це припускали автори [8-9]) або, наприклад, різних вантажів i виробів можна проводити або швидкими нейтронами (ШН) Ве-випромінювача ПВН, або тепловим полем того ж джерела, розташованого у центрі ПЕ сповільнювача. Отже, конструкція може застосовуватися не тільки для лікування онкологічних захворювань, але й при необхідності для опромінення ручної поклажі пасажирів аеропортів, поштових відправлень, виробів і вантажів 3 метою знаходження в їхньому складі ядерних матеріалів [10].

Заради справедливості відзначимо, що нейтрони для визначення ядер урану i плутонію в радіоактивних відходах

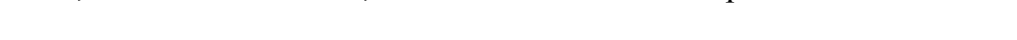


В експерименті [11] у матриці з 10 кг піску розміщувалися зразки ${ }^{238} \mathrm{U}$ з $2 \%$ збагаченням ${ }^{235} \mathrm{U}$. За час експозиції 600 с було виявлено мінімальну кількість ${ }^{235} \mathrm{U}-0.012$ г, що відповідало концентрації $1,2 \cdot 10^{-6} \Gamma \cdot \Gamma^{-1}$. Порівняння показує, що генератор на основі ПВН, є значно легшим, простішим, дешевшим, ніж складний, громіздкий, прив'язаний до наукового центру ЛПЕ-300, але, в той же час, має інтенсивність потоку приблизно на три порядки менше, що не дозволяє проводити дослідження певного класу.

\section{ПОШУК ЯДЕРНИХ МАТЕРІАЛІВ}

Під час митного огляду, перш за все, важливий сам факт негайного виявлення нелегального транспортування елементів поділу. Більш ретельна інспекція може бути проведена із застосуванням спеціального обладнання після затримання підозрілих громадян або транспорту. В роботі [10] показано, що існує реальна можливість знаходження ядерних матеріалів, якщо використовувати сповільнювачі 3 вмістом водню і імпульсні нейтронні генератори з виходом $\left(10^{7}-10^{8}\right) \mathrm{H} \cdot \mathrm{c}^{-1}$. Вміст ${ }^{235} \mathrm{U}$ i ${ }^{239} \mathrm{Pu}$ масою $(5-10)$ г можна визначити з ймовірністю 99,9\% за (5 - 7) с роботи. При цьому доглядові комплекси, які використовуються для запобігання обігу елементів поділу мають відповідати таким основним умовам [10]:

1. вихід нейтронного джерела визначається радіаційною обстановкою в обслуговуваних приміщеннях і не повинен перевищувати $\left(10^{7}-10^{8}\right) \mathrm{H} \cdot \mathrm{c}^{-1}$;

2. джерело випромінювання повинно вимикатися в перервах між циклами робіт;

3. не повинно бути радіоактивного забруднення приміщення навіть при повному руйнуванні джерела;

4. простота конструкції, малі розміри радіаційного захисту і порівняно низька вартість;

5. прийнятний час експлуатації без заміни джерела нейтронного випромінювання.

У перерахованих умовах роботи радіаційної небезпеки, пов'язаної з активацією досліджуваних предметів, немає. Лише поблизу зовнішньої поверхні установки існує зона розміром не більше 0,5 м, де рівень опромінення персоналу може перевищити граничні дози. Однак у цій зоні забезпечується автоматичне переміщення вантажу.

У багажній камері існує деякий нерівномірний розподіл щільності потоку ТН, обумовлений положенням джерела відносно об’єму, що інспектується. Але градієнт поля, в крайньому випадку, в разі імпульсного випромінювача, малий [10]. Як видно, описані вище вимоги для успішного визначення матеріалів, що діляться, повністю відповідають режимам роботи ПВН.

Пропонований експеримент являє собою послідовний ряд процедур. Джерело ШН нейтронів ПВН 3 інтенсивністю $10^{9} \mathrm{H} \cdot \mathrm{c}^{-1}$ розміщується в центрі ПЕ кулі. Вихідний потік, уповільнених до теплових енергій нейтронів, направляється на досліджуваний об'єкт. При наявності в об'ємі ядер поділу відбувається їх взаємодія $3 \mathrm{TH}$, у результаті чого вони розвалюються. Реакція супроводжується випромінюванням вторинних продуктів поділу.

На практиці моніторинг ТН, у більшості випадків проводиться пропорційними ${ }^{3}$ Не-лічильниками, заповненими сумішшю (95 - 97)\% ${ }^{3} \mathrm{He}$ і Ar. Детектори витримують опромінення до $\sim 10^{13} \mathrm{H} \cdot \mathrm{cm}^{-2}$ і реєструють відносно слабкі потоки в присутності $\gamma$-фону $\leq 1$ Р/год. Достатньо великий обсяг детектора, забезпечує хорошу ефективність взаємодії ТН $3{ }^{3}$ Не. Окрім того, за робочим діапазоном енергій, простоті конструкції, дешевизні, $\mathrm{i}$ пригніченням $\gamma$-квантів, лічильник перевершує інші моделі. У таблиці 1 показана імовірність взаємодії ТН і фотонів з матеріалами лічильника [12]. Видно, що має місце сильне пригнічення $\gamma$-квантів 3 енергією 1 МеВ.

Таблиця 1.

Імовірність взаємодії нейтронів і $\gamma$-квантів у пропорційному ${ }^{3}$ Не-лічильнику

\begin{tabular}{|c|c|c|}
\hline \multicolumn{2}{|c|}{ Тип материалу детектора } & \multicolumn{2}{|c|}{ Імовірність взаємодії } \\
\cline { 2 - 3 } & Теплові нейтрони & Фотони з енергією 1 МеВ \\
\hline${ }^{3}$ Не у трубці діаметром 2,5 см і тиском 2 атм & 0,77 & 0,0001 \\
\hline
\end{tabular}

Іноді, надмірно велика кількість $\gamma$-квантів небажана для того чи іншого дослідження, що вимагає застосування захисного екрана. Як правило, це свинець. При опроміненні детектора нейтронами поділу 3 енергією $1 \mathrm{MeB}$ у присутності $\gamma$-випромінювання 3 енергією $1 \mathrm{MeB}$ захист зі свинцю товщиною 5 см, поглинає 0,1\% нейтронів і 90\% $\gamma$-квантів [12].

У випадку реєстрації ШН, їх попередньо термалізуют до теплових енергій. На практиці було виявлено, що застосування сповільнювача збільшує габарити і вагу блоку детектування, а також знижує еффектівність реєстрації нейтронів до 10\% [13-14]. Один з перших ефективних лічильників ШН був розроблений у 1947 р. Це була довга камера, заповнена газом $\mathrm{BF}_{3}$ з 96\% збагаченням, і парафіновий сповільнювач. Ефективність реєстрації нейтронів практично не залежала від їх енергії в області 10 кеВ - 3 МеВ. У численних аналогах, створених у подальшому, діапазон енергії, що реєструється, мав обмеження $\leq 10 \mathrm{MeB}$. Значно пізніше T.W. Bonner із співробітниками запропонував систему [15], засновану на використанні сповільнювачів нейтронів сферичної форми і чутливого детектора, розміщеного у центрі. Устаткування дозволяє проводити вимірювання полів у діапазоні енергій від теплових до багатьох ГеВ. 
Зрозуміло, що з усієї кількості частинок, що виникають в результаті реакції поділу, в детектор потрапляє лише частина, пропорційна $S \cdot \varepsilon \cdot R^{-2}$, де $S$ - площа детектора, $\varepsilon$ - ефективність рахування детектора, $R$ - відстань до детектора. Тому, для підвищення ефективності реєстрації нейтронів бажано створити «лінійку детекторів», що утворюють замкнену систему навколо вимірювальної камери. У даному випадку на першому етапі

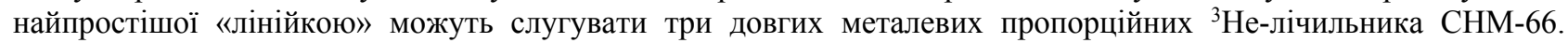
Діаметр 25,5 мм, довжина 601,5 мм, робоча напруга 1600 В, ефективність до ТН 80\% [16]. Даний детектор і його параметри обрані в якості прикладу з урахуванням середнього розміру ручної поклажі, дозволеної для провезення в авіалайнерах, $55 \times 40 \times 20$ см (по довжині, ширині, висоті) або 115 см у сумі по трьом вимірам [17].

Описані вище газонаповнені детектори розроблені в 60-х роках і до теперішнього часу їх характеристики іноді не відповідають висунутим вимогам. Нещодавно для контролю нейтронного потоку пройшли атестацію нові детектори на основі оксидних і напівпровідникових сцинтиляторів $[14,18]$ виробництва Харківського інституту сцинтиляційних матеріалів НАН України.

\section{РЕССТРАЦІЯ НЕЙТРОНІВ ТВЕРДОТІЛЬНИМИ ЛІЧИЛЬНИКАМИ}

Дослідження останнього десятиліття, показали, що детектори на базі оксидних і напівпровідникових сцинтиляторів реєструють теплові і швидкі нейтрони не гірше інших лічильників, що мають застосування в науці і техніці. Використання, наприклад, датчика нейтронного випромінювання на основі кристала $\mathrm{CdWO}_{4}$ або CWO показало, що він з успіхом замінює дорогі ${ }^{3} \mathrm{He}$ пропорційні лічильники [18]. Експериментально доведено можливість реєстрації ТН і ШН неорганічними сцинтиляторами з високим $Z_{\text {ефф }} 3$ ефективністю $(40-50) \%$, що в кілька разів вище, ніж у детекторах, що традиційно використовуються. Крім того, за рядом параметрів, таких як габарити, вага, дешевизна, навіть перевершують їх. Найбільш імовірним механізмом ефективної реєстрації нейтронів вважається реакція непружного розсіяння $\left(\mathrm{n}, \mathrm{n}^{\prime} \gamma\right)$. Недоліком сцинтиляторів $\epsilon$ те, що вони крім нейтронів активно реєструють $\gamma$ випромінювання. На рис. 2 наведена блок-схема пристрою, яким користувалися у всіх проведених експериментах [14]. Позначення: $1-{ }^{239} \mathrm{Pu}-\mathrm{Be} ; 2$ - кристал; 3 - ФЕП R1306; 4 - i 5 - поглинач TH GdO у вигляді циліндра діаметром 40 мм і кришки товщиною $d=10$ мм; 6 - і 7 - свинець $d=40$ і 4 мм, відповідно.

Ефективність реєстрації (ЕР) швидких нейтронів визначалася методом внутрішнього рахування $\gamma$-квантів, що з'являються в сцинтиляторі з реакції (n, n' $\gamma)$, які мають енергію $(10-300)$ кеВ. Оцінка ефективності та чутливості проведена за допомогою ${ }^{239} \mathrm{Pu}-В е$ джерела $(0,1-10,7) \mathrm{MeB}$ і системи детектування сцинтилятор - ФЕП, яка реєструвала фотони в різних енергетичних діапазонах. Крім того, вимірювання $\gamma$-спектрів розсіяних нейтронів, проводилися 3 випромінювачем ${ }^{252} \mathrm{Cf}$ і блоком реєстрації сцинтилятор - лавинний фотодіод ЛФД S 8664-55 Hamamatsu. Ефективність реєстрації ШН для CWO 10×10×10 мм³ в енергетичному діапазоні (70 - 800) кеВ 28\%.

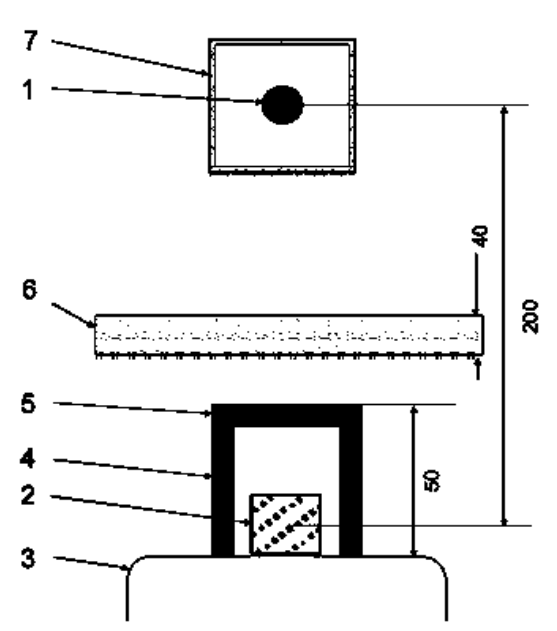

Рис. 2. Блок-схема установки

Спектри $\gamma$-випромінювання, здобуті при взаємодії ШН 3 різними типами сцинтиляторів розміром $10 \times 10 \times 10$ мм, показують, що ЕР швидких нейтронів мало відрізняються для сцинтиляторів одного і того ж розміру. Області енергій переважної реєстрації $\gamma$ квантів приблизно однакові для всіх досліджених зразків. У той же час чутливість детекторів пропорційна геометричним розмірам. Результати вимірювань ЕР [14] ШН і ТН сцинтиляторами CWO, DGO, GSO, ZnWO, ZnSe, LiI(Eu) та ін. в області енергій $(10-300)$ кеВ проілюстровані в таблиці 2. Наведені величини узгоджуються 3 даними, які відомі з літератури [19]. Наведені вище параметри оксидних і напівпровідникових сцинтиляторів 3 високим ефективним зарядом $Z_{\text {ефф }} \sim(33-75)$ і реєстрацією $\gamma$ випромінювання в енергетичному вікні $(10-300)$ кеВ, підходять для детектування миттєвих нейтронів вимушеного поділу ядер.

Відзначимо, що в експериментах $\gamma$-спектрометри вимірювали як повну швидкість рахування, тобто для всього діапазону енергій, так і незалежно по чотирьом енергетичним вікнам: 30 - 300, $300-1000,1000-1300,1300-3000$ кеВ. Це давало можливість підвищити чутливість системи при знаходженні конкретних джерел випромінювання, а також визначити тип ізотопу по ідентифікації вікна, де сталося виявлення (у випадку наявності одного типу ізотопу).

Таблиця 2.

Ефективність реєстрації, \%

\begin{tabular}{|c|c|c|c|c|c|c|c|c|c|}
\hline Сцинтилятор & ZnSe & NaJ & LiJ & CsJ & GSO & ZnWO & CWO & DGO & LiJ (реакція Li(n, $\alpha)$ T) \\
\hline$Z_{\text {ефф }}$ & 33 & 51 & 52 & 54 & 59 & 61 & 66 & 75 & 52 \\
\hline ШН & 43 & 18 & 25 & 20 & 46 & 54 & 42 & 48 & 0.66 \\
\hline TH & 0 & 30 & 90 & 0 & 65 & 44 & 67 & 34 & 93 \\
\hline
\end{tabular}




\section{ВИЯВЛЕННЯ ${ }^{235} \mathrm{U}$ I ${ }^{239} \mathrm{Pu}$ ЗА ДОПОМОГОЮ $\gamma$-ВИПРОМІНЮВАННЯ ПРИ $E_{\gamma}>4900$ кеВ}

Як відомо, продукти поділу крім нейтронів випромінюють також фотони, за допомогою яких можна визначити ізотопи поділу. Автори [20] запропонували використовувати для виявлення ${ }^{235} \mathrm{U}$ i ${ }^{239} \mathrm{Pu}$ високоенергетичну частину $\gamma$-спектра більше 4900 кеВ. У цьому випадку $\gamma$-випромінювання супутніх елементів не заважає аналізу. Висока енергія $\gamma$-квантів дає змогу обстежити масивні зразки, застосувати фільтрацію низькоенергетичного випромінювання. Особливості пропонованого підходу роблять його привабливим при розвідці родовищ урану, знаходження ізотопів поділу в закритих об'ємах, визначення відносного вмісту ${ }^{235} \mathrm{U}$ i ${ }^{239} \mathrm{Pu}$ у відпрацьованих і свіжих ТВЕЛ-ах і т.д. Для аналітичних вимірювань можуть бути використані реактор, нейтронний генератор, радіоізотопні джерела ${ }^{252} \mathrm{Cf}$ i ${ }^{239} \mathrm{PuBe}$.

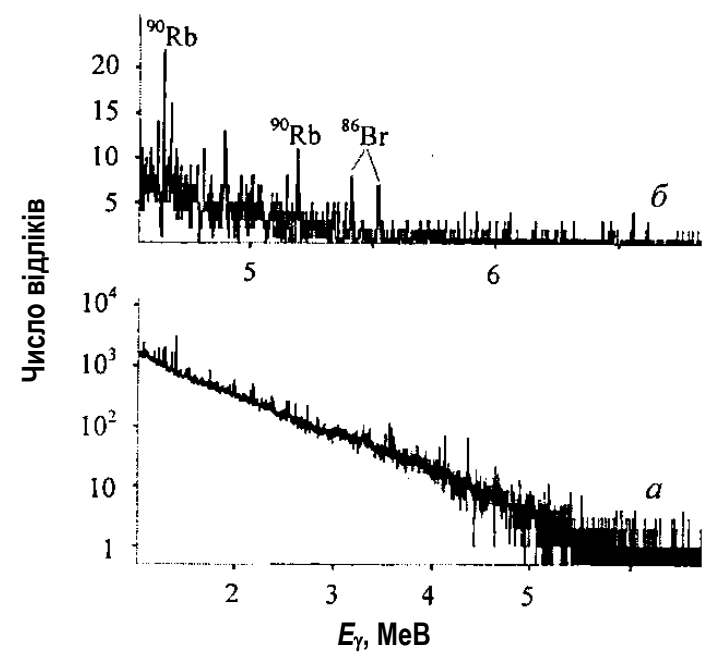

Рис. 3. $\gamma$-Спектр продуктів поділу ${ }^{235} \mathrm{U}$

Слід зазначити, що фотони, які виникають при взаємодії запізнілих нейтронів зразка, ні в якому разі не $\epsilon$ в пропонованому методі перешкодою. Їх реєстрація тільки підвищує ефективність методу. Для детектування $\gamma$ випромінювання крім напівпровідникового германієвого детектора (HPGe) з високим енергетичним розрізненням підходить і $\gamma$-спектрометр 3 кристалом $\mathrm{NaI}(\mathrm{Tl})$, який оснащений захистом від низькоенергетичного $\gamma$-випромінювання і нейтронів. При цьому особливу увагу слід звернути на коректний вибір нижньої межі використовуваного $\gamma$-спектра, щоб виключити можливий внесок ліній ${ }^{49} \mathrm{Ca}$ (4738 кеВ) i ${ }^{88} \mathrm{Rb}$ (4742 і 4853 кеВ) близьких до енергії 4900 кеВ. На рис. 3 наведено детальний $\gamma$-спектр продуктів поділу ${ }^{235} \mathrm{U}$, виміряний $\mathrm{HPGe}$ детектором на нейтронному пучку IP-8. Вимірювання проведено для діапазону 1000 - 6700 (a), 4550 - 6850 кеВ (б). Оптимальний режим роботи: $120 \mathrm{c}$ опромінення, $60 \mathrm{c}$ витримка і 120 с вимірювання.

Можливості визначення відносного вмісту ${ }^{235} \mathrm{U}$ i ${ }^{239} \mathrm{Pu}$ пов'язані 3 різним виходом деяких продуктів поділу. Зокрема, для чітко виражених у спектрі на рис. 3 піків ${ }^{86} \mathrm{Br} \mathrm{i}{ }^{90} \mathrm{Rb}$ виходи відрізняються в 3 рази. $\mathrm{He}$ виключено, що ще більш перспективним може виявитися виділення із спектру ліній нижче $5 \mathrm{MeB}$. Так, інтенсивність $\gamma$-ліній ${ }^{106} \mathrm{Tc} 2789$ і 3186 кеВ на акт поділу ${ }^{239} \mathrm{Pu}$ у 10 разів вище, ніж при поділі ${ }^{235} \mathrm{U}$.

\section{СПОНТАННИЙ ПОДІЛ ${ }^{235} \mathbf{U} \mathbf{~ i ~}^{239} \mathrm{Pu}$}

Визначення параметрів уранового зразка, засноване на вимірюванні природного $\gamma$-випромінювання ${ }^{235} \mathrm{U}, \epsilon$ широко використовуваним методом неруйнівного аналізу. Знаходження ядер урану і визначення ступеня його збагачення засновано на реєстрації одиночної $\gamma$-лінії 185,7 кеВ. Попередньо випромінювання пропускають через фільтр і коліматор. Фільтр поглинає $\gamma$-кванти в області енергій нижче 185,7 кеВ, а за допомогою коліматора встановлюється площа видимої детектором поверхні. $\gamma$-Лінія 185,7 кеВ утворюється з імовірністю $(57,5 \pm 0.9) \%$. Ї̈і питома інтенсивність $\sim 4,3 \cdot 10^{4} \mathrm{c}^{-1} \cdot \mathrm{r}^{-1}$ [12]. При віддаленні зразка від детектора у відсутності коліматора ефективність реєстрації буде зменшуватися за законом близьким до $1 / r^{2}$, де $r$-радіус детектора.

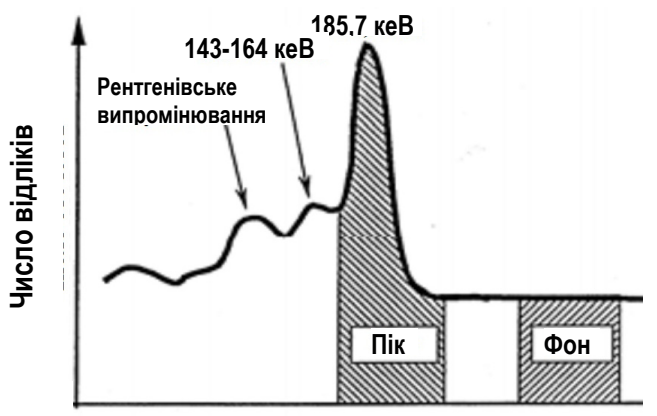

$\mathrm{У}$ той же час його використання дозволяє зменшити залежність від цього фактору, але не усуває ії повністю. Чим менше діаметр пропускного отвору, тим ближче реальна геометрія до ідеальної, тим менший вплив ефекту $1 / r^{2}$.

Якщо урановий зразок досить великий, то в його глибині $\gamma$-кванти повністю поглинаються і не дають ніякого вкладу на поверхні. Тобто, зі збільшенням товщини потік $\gamma$-променів на поверхні досягає рівноважного значення, яке практично не залежить від фізичної форми зразка. Для чистих уранових сумішей це значення пропорційне величині збагачення. Фотони бажано реєструвати напівпровідниковими HPGe-детектором. Висока енергетична роздільна здатність дозволяє повністю відокремити

Енергія, кеВ

Рис. 4. $\gamma$-спектр ${ }^{235} \mathrm{U}$, виміряний $\mathrm{NaI}(\mathrm{Tl})$ детектором пік 185,7 кеВ від сусідніх максимумів. Між ними з'являються рівні ділянки фону, що полегшує задачу визначення площі фотопіка i швидкості рахування. Однак можна отримувати дані, застосовуючи сцинтиляційний $\gamma$-спектрометр на основі монокристала $\mathrm{NaI}(\mathrm{Tl})$. Спектр $\gamma$-випромінювання ${ }^{235} \mathrm{U}$, виміряний $\mathrm{NaI}(\mathrm{Tl})$-детектором, показаний на рис. 4. Видно, що наявність у 
$\gamma$-спектрі окремого піка при енергії 185,7 кеВ вказує на присутність у досліджуваному об'ємі ${ }^{235} U$. Швидкість рахування в діапазоні навколо піку залежить не тільки від концентрації ${ }^{235} \mathrm{U}$ у зразку. Фотопік розташований на досить великій підкладці, яка представляе континуум спектра комптонівських електронів. Для калібрування системи детектування потрібен відповідний еталон - атестований урановий зразок. Точність аналізу залежить від ступеня збагачення і становить (1 - 5)\% при вимірюванні за допомогою $\mathrm{NaI}(\mathrm{Tl})$-детектора i $(0,1-1) \%$ для HPGe-детектора. Головний недолік методу вимірювання збагачення, заснованого на дослідженні лінії 175,7 кеВ - необхідність калібрування системи реєстрації для кожного нового контейнера зі зразком урану. Насправді існує три енергетичних діапазони в спектрі $\gamma$-випромінювання, які можна вибрати для визначення збагачення урану. Це 53 - 68, 84 - 130 і 185 - 1001 кеВ. Усі наведені діапазони включені до відповідних програмних кодів для розрахунку збагачення урану.

На результати аналізу за описаною схемою (фільтр, коліматор) можуть вплинути два фактори. Це неврахована при обчисленнях геометрія експерименту та інтерференція 3 іншими піками. Ще одна систематична похибка, що виникає при визначенні збагачення, це інтерференція $\gamma$-ліній 185,7 кеВ від ${ }^{235} \mathrm{U}$ i 186 кеВ продуктів поділу ${ }^{238} \mathrm{U}$. При хорошій роздільній здатності внесок від цього піка в досліджуваний фотопік 185,7 кеВ для природного урану складає всього $0,1 \%$ і стає дуже незначним при збільшенні збагачення. Відповідно для сильно збіднених зразків внесок від випромінювання ${ }^{238} \mathrm{U}$ слід враховувати.

Таблиця 3.

\begin{tabular}{|c|c|c|c|}
\hline \multirow{8}{*}{ Lleny NaI-детектор } & \multicolumn{3}{|c|}{ Спектральні області ${ }^{239} \mathrm{Pu}$} \\
\hline & \multirow{2}{*}{$\begin{array}{l}\text { Спектральні } \\
\text { області, кеВ }\end{array}$} & \multicolumn{2}{|r|}{${ }^{239} \mathrm{Pu}$} \\
\hline & & $\begin{array}{l}E_{\gamma}, \\
\text { кеВ }\end{array}$ & Інтенсивність, квант $\cdot c^{-1} \cdot \Gamma$ \\
\hline & $40-60$ & 51,63 & $6,19 \cdot 10^{5}$ \\
\hline & $90-105$ & 98,78 & $2,80 \cdot 10^{4}$ \\
\hline & $120-450$ & 129,3 & $1,44 \cdot 10^{5}$ \\
\hline & & 203,5 & $1,28 \cdot 10^{4}$ \\
\hline & & 345,0 & $1,28 \cdot 10^{4}$ \\
\hline 200 & & 375,0 & $3,60 \cdot 10^{4}$ \\
\hline Енергія, кеВ & & 413,7 & $3,42 \cdot 10^{4}$ \\
\hline $\begin{array}{l}\text { Pис. 5. } \gamma \text {-Спектр } \\
\text { виміряний } \mathrm{NaI}(\mathrm{Tl})-\text { і HPGe-детекторами }\end{array}$ & $450-800$ & 646,0 & $3,42 \cdot 10^{2}$ \\
\hline & & 717,7 & $6,29 \cdot 10^{1}$ \\
\hline
\end{tabular}

Що стосується плутонію, то метод неруйнівного аналізу ізотопного складу матеріалів, що містять плутоній (більшість зразків плутонію містять ${ }^{238} \mathrm{Pu},{ }^{239} \mathrm{Pu},{ }^{240} \mathrm{Pu},{ }^{241} \mathrm{Pu}$ i ${ }^{242} \mathrm{Pu}$ ), є найбільш розробленим методом i не вимагає калібрування за допомогою еталонів $[2,12]$. У розрахунках використовуються відомі значення фундаментальних фізичних констант і внутрішні калібрування. Цей підхід дозволяє проводити вимірювання ізотопного складу в зразках різних розмірів, форми, фізичного і хімічного складу всередині контейнерів 3 невідомими розмірами і хімічним вмістом. На рис. 5 наведений $\gamma$-спектр ${ }^{239} \mathrm{Pu} 393 \%$ збагаченням, виміряний HPGe- i NaI(Tl)-детекторами. Як видно з рисунка, плутоній не має одиночних, інтенсивних $\gamma$-ліній у спектрі, що помітно відрізняються від інших. Тому для ізотопних вимірювань використовуються відомі спектральні області, які наведені в таблиці 3. Принципові підходи, які використовуються для визначення збагачення урану, також можуть бути застосовані і для знаходження ізотопного складу плутонію. Хоча $\epsilon$ і ряд відмінностей. $\mathrm{У}$ даний час, для визначення ізотопного складу урану і плутонію найчастіше використовуються математичні коди, розроблені в Лос-Аламоській лабораторії (США). Це коди MGA (MGAU для визначення збагачення урану) i FRAM [12].

\section{ВИСНОВКИ}

Обговорюється перспектива створення автономної установки НДК «Прискорювач» ННЦ ХФТІ для виявлення ядерних матеріалів, що діляться, у виробах і вантажах, у тому числі і тих, що знаходяться в замкнутих об'ємах. Розглянуто різні варіанти аналізу, що включають опромінення досліджуваних зразків опорним полем теплових нейтронів; реєстрацію миттєвих нейтронів поділу не тільки традиційним способом за допомогою поліетиленового сповільнювача і пропорційного ${ }^{3}$ Не-детектора, а також без сповільнювача, застосовуючи оксидні або напівпровідникові сцинтилятори, що прямим чином перетворюють енергію випромінювання в електричний сигнал; підходи, які використовують високоенергетичну частину $\gamma$-спектра уламків поділу більше 4900 кеВ, а також метод, що застосовано в пасивному неруйнівному аналізі ${ }^{235} \mathrm{U}$, який 
заснований на вимірюванні та аналізі $\gamma$-лінії з енергією 185,7 кеВ. Показано, що запропонована установка здатна визначити присутність найбільш важливих ядерних матеріалів у досліджуваних виробах, поштових відправленнях, багажі пасажирів і т. д.

\section{ORCID IDs}

Eduard L. Kuplennikov, https://orcid.org/0000-0001-9102-3459; (Dykola I. Ayzatsky, https://orcid.org/0000-0003-4706-9614; (D) Alexander N. Vodin, https://orcid.org/0000-0002-3774-1051; DOlexii S. Deiev, https://orcid.org/0000-0003-4565-9039; DStanislav N. Olejnik, https://orcid.org/0000-0003-0300-0658; (DIryna S. Timchenko, https://orcid.org/0000-0003-2917-5026; DSergii S. Kandybei, https://orcid.org/0000-0003-3598-0427

\section{REFERENCES}

[1] M. Gaisinsky, and J. Adlov, Радиохимический словарь элементов [Radiochemical Dictionary of Elements], (Atomizdat, Moscow, 1968), pp. 255. (in Russian)

[2] I.N. Beckman, Ядерное оружие [Nuclear Weapons], (MGU, Moscow, 2010), pp. 21. (in Russian), www.profbeckman.narod.ru/Uran.files/Glava15.pdf. (in Russian)

[3] S.G. Plachkova, in: Физические основы работы ядерных реакторов, [Physical bases of operation of nuclear reactors], (Energetika, Kyiv, 2013). (in Russian)

[4] I.N. Beckman, Ядерная Физика. Курс лекиий [Nuclear physics. Lecture course], (MGU, Moscow, 2010), pp. 511. (in Russian)

[5] V. Krasilnikov, and E. Kuplennikov, Danish Scientific Journal. http://www.danish-science.org/wpcontent/uploads/2020/02/DSJ_32_1.pdf.

[6] E.A. Belogorlov, G.I. Britvich, G.I. Krupny, V.N. Lebedev, V.S. Lukanin, A.V. Makagonov, V.N. Peleshko, and Ya.N. Blooming, Методические вопросы применения многошарового спектрометра Боннера в радиационных исследованиях [Methodological issues of using the Bonner multi-ball spectrometer in radiation research], (PREPRINT IFVE 85-3, Serpukhov, 1985), pp. 22. (in Russian)

[7] Yu.V. Mokrov, and S.V Morozova, Pisma v ECHAYA, 11(2), 219-232 (2014), (in Russian), http://www1.jinr.ru/Pepan letters/panl 2014 2/10 mok.pdf

[8] A.N. Dovbnya, V.A. Tsymbal, A.F. Stoyanov, D.Y. Shahov, and I.N. Zaytsev, Problems of atomic science and technology. Series: "Nucl. Phys. Invest.", 3(103), 84-86 (2016), https://vant.kipt.kharkov.ua/ARTICLE/VANT 2016 3/article 2016 3 84.pdf.

[9] A.F. Stoyanov, A.N. Dovbnya, and V.A. Tsymbal, Problems of atomic science and technology. Series: "Nucl. Phys. Invest.", 6(112), 172-174 (2017), https://vant.kipt.kharkov.ua/ARTICLE/VANT_2017_6/article_2017_6_172.pdf.

[10] V.L. Romodanov, V.V. Afanasyev, A.G. Belevitin, V.K. Sakharov, and A.A. Ignatov, Atomnaya Energiya, 101(2), 125-130 (2006), (in Russian), http://elib.biblioatom.ru/text/atomnaya-energiya_t101-2_2006/go,0/.

[11] V.V. Kirichenko, L.A. Makarenko, and V.I. Noga, Problems of atomic science and technology. Series "Nucl. Phys. Invest.", 2(41), 111-115 (2003), https://vant.kipt.kharkov.ua/ARTICLE/VANT_2003_2/article_2003_2_111.pdf.

[12] V.I. Boyko, and M.E. Silaev, Mетоды и приборы для измерения ядерных и других радиоактивных материалов [Methods and instruments for measuring nuclear and other radioactive materials], (MNTTs, Moscow, 2011), pp. 356. (in Russian)

[13] A.Yu. Buki, and S.A. Kalenik, Journal of Kharkov National University. Series: "Nuclei, Particle, Fields", 2(54), 110-113 (2012), (in Russian), https://periodicals.karazin.ua/eejp/article/view/13828/13019.

[14] V.D. Ryzhikov, Международная конференция ИСМА НАН Украины «Разработка сцинтилляиионных детекторов и создание устройств на их основе» [International Conference ISMA NAS of Ukraine "Development of scintillation detectors and creation of devices based on them"], (KHISM, Kherkov, 2012) pp. 1-35. (in Russian), www.2012.ismart.kharkov.ua/presentations/23/23 11-00 Ryzhikov.pdf.

[15] R.L. Blamblett, R.J. Ewing, and T.W. Bonner, Nuclear instrument and methods, 9, 1-12 (1960), https://doi.org/10.1016/0029-554X(60)90043-4.

[16] M.L. Baranochnikov, Приемники и детекторы излучений. Справочник [Radiation receivers and detectors. Reference Book], (DMK Press, Moscow, 2012), pp. 640. (in Russian)

[17] A. Zakharova, Как правильно перевозить ручную кладь в самолете. Размер и вес ручной клади [Hоw to properly transport hand luggage on the plane. Size and weight of carry-on baggage], (Skyscanner, Moscow, 2019), pp. 2-3. (in Russian), https://www.skyscanner/ru/news/pravila-provoza-ruchnoi-kladi.

[18] V.D. Ryzhikov, B.V. Grynyov, G.M. Onishchenko, L.A. Piven, O.K. Lysetska, L.L. Nagornata, I.M. Zenya, and A.Y. Berezhnoy, Telecommunications and Radio Engineering, 71(18), 1665-1686 (2012), https://doi.org/10.1615/TelecomRadEng.v71.i18.50.

[19] M. Anelli, G. Battistoni, S. Bertolucci, C. Bini, P. Branchini, C. Curceanu, G. De Zorzi, A. Di Domenico, B. Di Micco, A. Ferrarie, P. Gauzz, S. Giovannella, F. Happacher, M. Iliescu, M. Martini, S. Miscetti, F. Nguyen, A. Passeri, A. Prokofiev, P. Sala, B. Siascia, and F. Sirghi, Nuclear instrument and methods, A580, 368-372 (2007), https://doi.org/10.1016/j.nima.2007.08.005.

[20] A.M. Demidov, L.I. Govor and I.V. Mikhailov, Atomnaya Energiya, 98(5), 365-370 (2005), (in Russian), $\mathrm{http}: / /$ elib.biblioatom.ru/text/atomnaya-energiya_t98-5_2005/go,0/.

\section{АВТОНОМНА НЕЙТРОННА УСТАНОВКА ДЛЯ ВИЯВЛЕННЯ ЯДЕРНИХ МАТЕРІАЛІВ, ЩО ДІЛЯТЬСЯ Е.Л. Купленніков, М.І. Айзацкий, О.М. Водін, О.С. Деєв, С.М. Олійник, І.С. Тімченко, С.С. Кандибей, О.С. Качан, Л.П. Корда, Ю.М. Солодовніков ННЦ «Харківський фізико-технічний інстітут», 61108, Харків, Академічна 1}

Обговорюється перспектива створення автономної нейтронної установки для виявлення ядерних матеріалів, що діляться, у зразках, у тому числі і в тих, що знаходяться у замкнутих об'ємах. Пропонується на основі поліетиленового шарасповільнювача і портативного джерела швидких нейтронів, розробленого в НДК «Прискорювач» ННЦ ХФТІ на базі 
електростатичного прискорювача дейтронів безперервної дії, отримати опорне поле теплових нейтронів. Отримане джерело теплових нейтронів планується використовувати для активації невеликих виробів і вантажів з метою виявлення в їхньому складі заборонених для переміщення речовин, що містять ${ }^{233} \mathrm{U},{ }^{235} \mathrm{U}$ i ${ }^{239} \mathrm{Pu}$. Оперативне знаходження елементів поділу буде свідчити про спробу їх нелегального транспортування. Більш ретельна інспекція може бути проведена із застосуванням спеціального обладнання після затримання підозрілих вантажів, громадян або транспорту. Розглянута можливість реєстрації миттєвих нейтронів не тільки традиційним способом за допомогою поліетиленового сповільнювача $\mathrm{i}$ пропорційного ${ }^{3} \mathrm{He}$ детектора, але і без використання будь-якого сповільнювача, використовуючи оксидні або напівпровідникові сцинтилятори. Для виявлення матеріалів, що діляться, обгрунтовано метод використання високоенергетичної частини $\gamma$-спектру уламків поділу (більше 4900 кеВ), а також підхід, що застосовується у пасивному неруйнівному аналізі ${ }^{235} \mathrm{U}$ за $\gamma$-лінією 3 $E_{\gamma}=185,7$ кеВ. Доведено, що запропонована установка для виявлення ядерних матеріалів, що діляться, здатна за допомогою методу неруйнівного контролю визначити присутність ізотопів ${ }^{233} \mathrm{U},{ }^{235} \mathrm{U}$ i ${ }^{239} \mathrm{Pu}$ у досліджуваних виробах і вантажах.

КЛЮЧОВІ СЛОВА: ядерні матеріали, що діляться, неруйнівний аналіз, джерело нейтронів, сповільнювач, теплові нейтрони, уламки поділу, миттєві нейтрони

\section{АВТОНОМНАЯ НЕЙТРОННАЯ УСТАНОВКА ДЛЯ ОБНАРУЖЕНИЯ ДЕЛЯЩИХСЯ ЯДЕРНЫХ МАТЕРИАЛОВ Э.Л. Купленников, Н.И. Айзацкий, А.Н. Водин, А.С. Деев, С.Н. Олейник, И.С. Тимченко, \\ С.С. Кандыбей, А.С. Качан, Л.П. Корда, Ю.Н. Солодовников ННЦ «Харьковский физико-технический институт», 61108, Харьков, Академическая 1}

Обсуждается перспектива создания автономной нейтронной установки для выявления делящихся ядерных материалов в образцах, в том числе и находящихся в замкнутых объемах. Предлагается на основе полиэтиленового шара-замедлителя и портативного источника быстрых нейтронов, разработанного в НИК «Ускоритель» ННЦ ХФТИ на базе электростатического ускорителя дейтронов непрерывного действия, получить опорное поле тепловых нейтронов. Полученный источник тепловых нейтронов планируется использовать для активации небольших изделий и грузов с целью выявления в их составе запрещенных к перемещению веществ, содержащих ${ }^{233} \mathrm{U},{ }^{235} \mathrm{U}$ и ${ }^{239} \mathrm{Pu}$. Оперативное нахождение делящихся элементов будет свидетельствовать о попытке их нелегальной транспортировки. Более тщательная инспекция может быть проведена с применением специального оборудования после задержания подозрительных грузов, граждан или транспорта. Рассмотрена возможность регистрации мгновенных нейтронов деления не только традиционным способом с помощью полиэтиленового замедлителя и пропорционального ${ }^{3}$ Не-детектора, но и без применения какого-либо замедлителя, используя оксидные или полупроводниковые сцинтилляторы. Для обнаружения делящихся материалов обоснован метод использования высокоэнергетической части $\gamma$-спектра осколков деления (больше 4900 кэВ), а также подход, применяемый в пассивном неразрушающем анализе ${ }^{235} U$ по $\gamma$-линии с $E_{\gamma}=185,7$ кэВ. Показано, что предложенная установка для выявления делящихся ядерных материалов способна с помощью метода неразрушающего контроля определить присутствие изотопов ${ }^{233} \mathrm{U},{ }^{235} \mathrm{U}$ и ${ }^{239} \mathrm{Pu}$ в исследуемых изделиях и грузах.

КЛЮЧЕВЫЕ СЛОВА: ядерные делящиеся материалы, неразрушающий анализ, источник нейтронов, замедлитель, тепловые нейтроны, осколки деления, мгновенные нейтроны 